University of Nebraska - Lincoln

DigitalCommons@University of Nebraska - Lincoln

Agronomy \& Horticulture -- Faculty Publications

Agronomy and Horticulture Department

$11-1-2002$

\title{
Detection of Phosphorus and Nitrogen Deficiencies in Corn Using Spectral Radiance Measurements
}

\author{
S.L. Osbourne \\ University of Nebraska-Lincoln \\ James S. Schepers \\ University of Nebraska-Lincoln, james.schepers@gmail.com \\ D. Francis \\ University of Nebraska-Lincoln \\ Michael R. Schlemmer \\ University of Nebraska-Lincoln, michael.schlemmer@bayer.com
}

Follow this and additional works at: https://digitalcommons.unl.edu/agronomyfacpub

Part of the Plant Sciences Commons

Osbourne, S.L.; Schepers, James S.; Francis, D.; and Schlemmer, Michael R., "Detection of Phosphorus and Nitrogen Deficiencies in Corn Using Spectral Radiance Measurements" (2002). Agronomy \& Horticulture -Faculty Publications. 7.

https://digitalcommons.unl.edu/agronomyfacpub/7

This Article is brought to you for free and open access by the Agronomy and Horticulture Department at DigitalCommons@University of Nebraska - Lincoln. It has been accepted for inclusion in Agronomy \& Horticulture -Faculty Publications by an authorized administrator of DigitalCommons@University of Nebraska - Lincoln. 


\title{
Agronomy Journal
}

\section{REMOTE SENSING}

\section{Detection of Phosphorus and Nitrogen Deficiencies in Corn Using Spectral Radiance Measurements}

\author{
S. L. Osborne,* J. S. Schepers, D. D. Francis, and M. R. Schlemmer
}

\begin{abstract}
Applications of remote sensing in crop production are becoming increasingly popular due in part to an increased concern with pollution of surface and ground waters due to over-fertilization of agricultural lands and the need to compensate for spatial variability in a field. Past research in this area has focused primarily on $\mathbf{N}$ stress in crops. Other stresses and the interactions have not been fully evaluated. A field experiment was conducted to determine wavelengths and/or combinations of wavelengths that are indicative of $P$ and $\mathbf{N}$ deficiency and also the interaction between these in corn (Zea mays $\mathbf{L}$.). The field experiment was a randomized complete block design with four replications using a factorial arrangement of treatments in an irrigated continuous corn system. The treatment included four $N$ rates $(0,67$, 134 , and $\left.269 \mathrm{~kg} \mathrm{~N} \mathrm{ha}^{-1}\right)$ and four $P$ rates $\left(0,22,45\right.$, and $\left.67 \mathrm{~kg} \mathrm{Pha}^{-1}\right)$. Spectral radiance measurements were taken at various growth stages in increments from 350 to $1000 \mathrm{~nm}$ and correlated with plant $\mathrm{N}$ and $P$ concentration, plant biomass, grain $N$ and $P$ concentration, and grain yield. Reflectance in the near-infrared (NIR) and blue regions was found to predict early season $P$ stress between growth stages V6 and V8. Late season detection of $P$ stress was not achieved. Plant $N$ concentration was best predicted using reflectance in the red and green regions of the spectrum, while grain yield was estimated using reflectance in the NIR region, with the particular wavelengths of importance changing with growth stage.
\end{abstract}

$\mathrm{N}$ ITROGEN Is the most limiting nutrient in production of nonleguminous crops in central Nebraska and the Great Plains. As cropping practices become more intensive, other nutrients will likely become limiting as well. The second most limiting nutrient for corn production is often P. Current methods for estimating the amount of $\mathrm{P}$ available to growing crops include soil sampling or in-season plant sampling, both of which can be costly and labor intensive. The use of remote sensing

S.L. Osborne, Dep. of Agronomy, Univ. of Nebraska, Lincoln, NE 68583, currently at USDA-ARS, Northern Grain Insects Res. Lab., 2923 Medary Ave., Brookings, SD 57006; and J.S. Schepers, D.D. Francis, and M.R. Schlemmer, Dep. of Agronomy and USDA-ARS, Univ. of Nebraska-Lincoln, Lincoln, NE 68583. Received 3 Apr. 2000.

*Corresponding author (sosborne@ngirl.ars.usda.gov).

Published in Agron. J. 94:1215-1221 (2002). techniques to estimate nutrient status could decrease the amount of labor needed for sampling, and could reduce the cost associated with sampling and analysis.

Destructive tissue testing is a common way to assess crop $\mathrm{N}$ and $\mathrm{P}$ status. Nondestructive methods have been developed to monitor crop $\mathrm{N}$ status. Blackmer and Schepers (1994) found that the chlorophyll meter was a useful method of monitoring corn $\mathrm{N}$ status, compared with measuring leaf $\mathrm{N}$ concentration, which requires destructive sampling. While the chlorophyll meter is a good indicator of in-season $\mathrm{N}$ status, the technique requires time and labor for data collection. The use of remote sensing could help eliminate the need for extensive field sampling while still providing a good detection of deficiencies.

Remote sensing is simply obtaining information about an object, area, or phenomenon by analyzing data acquired by a device that is not in contact with the object, area, or phenomenon (Lillesand and Kiefer, 1987). Recently, researchers have evaluated remote sensing techniques for estimating the $\mathrm{N}$ status of growing crops by determining the appropriate wavelength or combination of wavelengths to characterize crop $\mathrm{N}$ deficiency. Blackmer et al. (1994) stated that light reflectance near $550 \mathrm{~nm}$ (green) was best for separating $\mathrm{N}$ treatment differences, and could be used to detect $\mathrm{N}$ deficiencies in corn. Everitt et al. (1985) studied the relationship of plant leaf $\mathrm{N}$ concentration and leaf reflectance from 500 to $750 \mathrm{~nm}$, concluding that buffalograss (Buchloe engelm Poaceae) receiving no fertilizer $\mathrm{N}$ had highest reflectance readings. Walburg et al. (1982) demonstrated that $\mathrm{N}$ treatments affected reflectance in both the red and near-infrared (NIR) regions of the spectrum, with red reflectance increasing and NIR reflectance decreasing for N-deficient corn canopies. Blackmer et al. (1996) reported that reflected radiation near 550 and $710 \mathrm{~nm}$ was better for detecting $\mathrm{N}$ deficiencies compared with reflectance at other wavelengths. They found that a ratio of the 550 to $600 \mathrm{~nm}$ band to the 800 to $900 \mathrm{~nm}$ band could distinguish between $\mathrm{N}$ treatments in irrigated corn canopies. Stone et al. (1996) demonstrated that total 
plant $\mathrm{N}$ could be estimated by using spectral radiance measurements at the red $(671 \mathrm{~nm})$ and NIR $(780 \mathrm{~nm})$ wavelengths. They calculated a plant-N-spectral-index for the amount of fertilizer $\mathrm{N}$ required to correct inseason $\mathrm{N}$ deficiency in winter wheat (Triticum aestivum L.). Yoder and Pettigrew-Crosby (1995) estimated total $\mathrm{N}$ and chlorophyll content using reflectance. They found that for fresh plant samples, the log transform of $1 /$ reflectance in the short-wave infrared band was the best predictor of $\mathrm{N}$ content and that the visible bands were the best predictors of chlorophyll content.

There has been limited research investigating the potential of using remote sensing techniques to detect $\mathrm{P}$ and other nutrient deficiencies. Milton et al. (1991) grew soybean [Glycine $\max (\mathrm{L}$.) Merr.] plants in hydroponic solutions at three $\mathrm{P}$ concentrations and measured weekly changes in leaf spectral reflectance. They found that P-deficient plants had a higher reflectance in the green and yellow portions of the spectrum and did not show the normal shift of the red edge (chlorophyll absorption band at $680 \mathrm{~nm}$ ). Al-Abbas et al. (1974) found that absorption at 830, 940, and $1100 \mathrm{~nm}$ was lower for $\mathrm{P}$ - and $\mathrm{Ca}$-deficient corn leaves, whereas leaves deficient in $\mathrm{S}, \mathrm{Mg}, \mathrm{K}$, and $\mathrm{N}$ had higher absorption in these wavelengths. Work by Masoni et al. (1996) found that Fe, $\mathrm{S}, \mathrm{Mg}$, and $\mathrm{Mn}$ deficiencies decreased absorption and increased reflectance and transmittance in corn, wheat, barley (Hordeum vulgare L.) and sunflower (Helianthus annuus L.) leaves. They also noted that mineral deficiency affected leaf concentration of other elements in addition to the deficient element, with nutrient concentrations varying according to species and deficiency level. Sembiring et al. (1998) found that by using a covariate of $435 \mathrm{~nm}$, a 695/405 nm ratio was a good indication of $\mathrm{P}$ uptake by bermudagrass [Cynodon dactylon (L.) Pers.].

The objectives of this experiment were to determine wavelengths and/or combinations of wavelengths that are indicative of $\mathrm{P}$ and $\mathrm{N}$ stresses independently and the interaction between these using hyperspectral data in irrigated corn.

\section{MATERIALS AND METHODS}

A continuous irrigated corn experiment was conducted on a Hord silt loam (fine-silty, mixed, mesic Pachic Haplustolls) located at the Management Systems Evaluation Area (MSEA) project near Shelton, NE. The production system utilized conventional tillage with a linear drive irrigation system. Total irrigation amounts were $200.8 \mathrm{~mm}$ during 1997 and $115.2 \mathrm{~mm}$ during 1998. Growing conditions during 1997 and 1998 were similar with respect to average daily temperature and growing degree days, but rainfall amount was different between the 2 yr with $247 \mathrm{~mm}$ for 1997 compared with $457 \mathrm{~mm}$ in the 1998 season. The seeding rate was 74000 plants ha ${ }^{-1}$ with Pioneer brand hybrid 3225 planted on 1 May 1997 and 4 May 1998. Initial surface soil test characteristics are reported in Table 1.

Table 1. Initial surface soil test characteristics.

\begin{tabular}{lcccccc}
\hline Depth & $\mathrm{pH}$ & Organic matter & $\mathrm{NO}_{3}-\mathrm{N}$ & $\mathrm{P}$ & $\mathrm{Zn}$ & $\mathrm{K}$ \\
\hline & & $\%$ & \multicolumn{4}{c}{$\mathrm{mg} \mathrm{kg}^{-1}$} \\
\cline { 4 - 7 } Surface & 6.5 & 1.8 & 21.5 & 7.0 & 1.44 & 493 \\
\hline
\end{tabular}

The experimental design was a randomized complete block design with four replications. The treatment design was a four $\times$ four factorial arrangement. Nitrogen was applied as $\mathrm{NH}_{4} \mathrm{NO}_{3}$ at rates of $0,67,134$, and $269 \mathrm{~kg} \mathrm{~N}^{-1}$, and $\mathrm{P}$ was applied as triple superphosphate at rates of $0,22,45$, and $67 \mathrm{~kg}$ $\mathrm{P} \mathrm{ha}^{-1}$. Phosphorus and a split application of $\mathrm{N}$ at one-half the $\mathrm{N}$ rate was applied preplant and incorporated. The second split $\mathrm{N}$ application at one-half the $\mathrm{N}$ rate was topdressed at V5 to V7. Treatments were applied to the same experimental areas both growing seasons. Plots were 9.14 by $15.24 \mathrm{~m}$ with $0.76 \mathrm{~m}$ row spacing. 'Guardsman' [dimethenamid (2-chloro$N$-[(1-methyl-2-methoxy)ethyl]- $N$-(2,4-dimethyl-thien-3-yl)acetamide) + atrazine (2-chloro-4-ethylamino-6-isopropylamino-s-trazine)] $53.2 \%$ a.i. were applied to all plots at a rate of $3.5 \mathrm{~L} \mathrm{ha}^{-1}$ in early May. Phenology data according to Ritchie et al. (1997) were recorded weekly from 1 June until the end of August.

Hyperspectral reflectance measurements were collected from 350 to $1000 \mathrm{~nm}$ (1.4 nm intervals) with a Personal Spectrometer II manufactured by Analytical Spectral Devices ${ }^{1}$ (Boulder, CO). A typical vegetation spectral curve with corresponding color reflected by at each wavelength is illustrated in Fig. 1. Six canopy measurements were taken randomly at a height of $3 \mathrm{~m}$ above the canopy with a $15^{\circ}$ field of view throughout each plot. Spectral measurements were collected 19 June and 15 July in 1997; and 19, 24, and 29 June and 20 July in 1998. Sampling dates were 19 June and 15 July in 1997; and 19 June and 20 July in 1998. Spectral measurements collected 19 June 1997 were collected without consideration for row position within the field of view. Spectral measurement collected after 19 June 1997 were collected by centering the field of view over a row to minimize the presence of soil. All readings were averaged to obtain a representative reading for the entire plot. Canopy measurements were taken on cloudfree days at $\pm 2 \mathrm{~h}$ from solar noon. All measurements were transformed into percent reflectance using a Spectralon ${ }^{1}$ reference panel (Labsphere, Sutton, NH) for determining total reflected incoming radiation. Panel measurements were taken before initial canopy readings and repeated approximately every $15 \mathrm{~min}$.

Integrating sphere measurements were collected on 17

${ }^{1}$ Mention of trade name or proprietary products does not indicate endorsement of USDA and does not imply its approval to the exclusion of other products that may also be suitable.

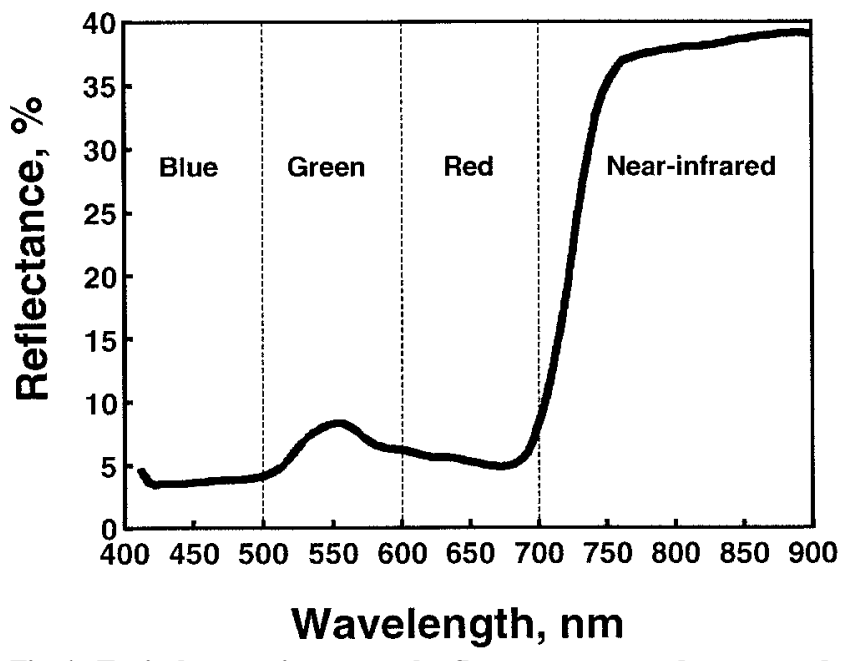

Fig. 1. Typical vegetation spectral reflectance curve and corresponding color reflected at each particular wavelength. 
and 23 June and 29 July in 1997 on the $269 \mathrm{~kg} \mathrm{~N}^{-1}$ rate for the four different $\mathrm{P}$ treatments. Integrating sphere measurements were collected on 10 random uppermost collared leaves. Leaves were placed in a Ziploc bag and stored on ice until measurements were performed. Three spot readings per leaf were taken on the upper and underside of the leaf surface. Spectral measurements were taken by attaching the radiometer to an 1800-12 External Integrating Sphere manufactured by Li-Cor Inc. ${ }^{1}$ (Lincoln, NE). External Integrating Sphere is a self-contained light source that collects spectral measurements on a $1-\mathrm{cm}$ diameter circle of the leaf without interference from external light and/or environmental conditions. All readings taken from the plots were averaged and transformed to percent reflectance using a barium sulfate reference to obtain one representative reading per plot.

Spectral readings were collected throughout the growing season and averaged over 5-nm intervals to decrease the amount of data for analysis. Analysis of variance and singledegree-of-freedom contrasts were performed, using the GLM procedure in SAS (SAS Inst., 1988). Stepwise regression was performed, using the REG procedure in SAS (SAS Inst., 1988), on all data to develop multiple regression equations for predicting plant $\mathrm{N}$ and $\mathrm{P}$ concentration, biomass, grain yield, and grain $\mathrm{N}$ and $\mathrm{P}$ concentration.

Aboveground biomass sampling was performed throughout the growing season by taking 12 randomly selected plants from the east quarter of the plots. Whole plants were weighed and ears were separated once distinguishable. Sampling dates were 19 June, 15 July in 1997, and 19 June and 20 July in 1998. Whole plants were chopped with a chipper-shredder in the field to facilitate subsampling. Subsamples were weighed, oven-dried at $50^{\circ} \mathrm{C}$, and then reweighed for water content. Leaf samples collected for integrating sphere measurements were saved for nutrient analysis. Leaf samples and ear samples were also ovendried at $50^{\circ} \mathrm{C}$ before weighing. All samples were ground with a Wiley Mill to pass a 2-mm sieve. Nitrogen concentration was determined on all samples using dry combustion (Schepers et al., 1989) and $\mathrm{P}$ concentration using energy dispersive $\mathrm{x}$-ray fluorescence (Knudsen et al., 1981). Total dry matter per plot was calculated by combining the ear and total vegetative matter dry weights. Grain yield was estimated by hand harvesting $3.05-\mathrm{m}$ row length from each of the four middle rows. Ears were shelled and water content determined. Grain samples were oven-dried at $50^{\circ} \mathrm{C}$, ground, and analyzed as described above for biomass samples. Grain yield per plot was calculated and corrected to $155 \mathrm{~g}$ moisture $\mathrm{kg}^{-1}$.

\section{RESULTS AND DISCUSSION \\ In-Season Biomass and Grain Harvest}

A significant linear and/or quadratic response to applied $\mathrm{N}$ was observed for all sampling dates for $\mathrm{N}$ content, grain yield, and biomass (Table 2-4). A significant biomass response to applied P in late June of 1997 and 1998 was observed (Tables 2 and 3). Later season biomass sampling in July did not exhibit a significant response to applied $\mathrm{P}$. Biomass production increased with increasing $\mathrm{N}$ rate for the second growing season, while increasing $\mathrm{N}$ rate decreased $\mathrm{P}$ content (Table 3 ). Plots receiving no $\mathrm{N}$ had a higher $\mathrm{P}$ content compared with the $\mathrm{N}$ fertilized plots for all sampling dates. This could be due to the reduction in growth from an $\mathrm{N}$ deficiency. The response to applied $\mathrm{N}$ was greater for $1998 \mathrm{com}$ pared with 1997 . There was a $26 \%$ increase in biomass production for the $269 \mathrm{~kg} \mathrm{~N}^{-1}$ rate compared with the $0 \mathrm{~kg} \mathrm{~N} \mathrm{ha}^{-1}$ rate for the June 1997 sampling date, whereas the 1998 June sampling date had a $232 \%$ increase in biomass. Differences in biomass sampling for late July did not exhibit the same variation between the 2 yr. The 1997 sampling had an increase of $26 \%$ compared with $105 \%$ increase in 1998. This increase in

Table 2. Analysis of variance, $\mathbf{N}$ and $\mathbf{P}$ rates means, and single degree of freedom contrasts for biomass, $N$, and $P$ concentration by sampling date, 1997.†

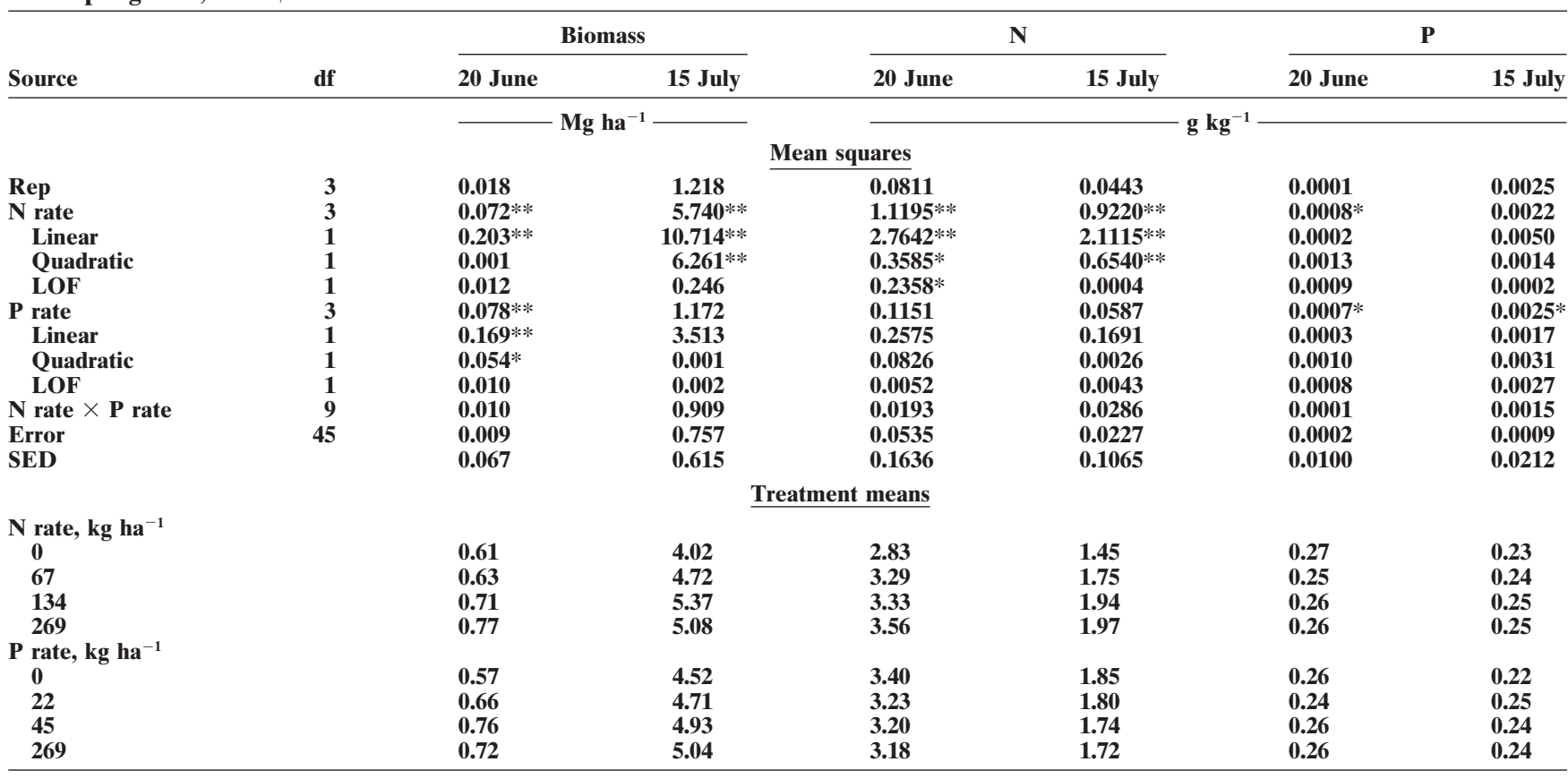

* Significant at the 0.05 probability level.

** Significant at the 0.01 probability level.

$\dagger$ df, degrees of freedom; LOF, lack of fit; SED, standard error of the difference between two equally replicated means. 
Table 3. Analysis of variance, $N$ and $P$ rates means, and single degree of freedom contrasts for biomass, $N$, and $P$ concentration by sampling date, 1998. $\dagger$

\begin{tabular}{|c|c|c|c|c|c|c|c|}
\hline \multirow[b]{2}{*}{ Source } & \multirow[b]{2}{*}{ df } & \multicolumn{2}{|c|}{ Biomass } & \multicolumn{2}{|c|}{$\mathbf{N}$} & \multicolumn{2}{|c|}{$\mathbf{P}$} \\
\hline & & 19 June & 20 July & 19 June & 20 July & 19 June & 20 July \\
\hline & & \multicolumn{2}{|c|}{$\mathrm{Mg} \mathrm{ha}^{-1}$} & \multicolumn{4}{|c|}{$\mathrm{g} \mathrm{kg}^{-1}$} \\
\hline \multicolumn{8}{|c|}{ Mean squares } \\
\hline Rep & 3 & 0.007 & 8.173 & 0.4468 & 0.0245 & 0.0113 & 0.0047 \\
\hline $\mathbf{N}$ rate & 3 & $1.149 * *$ & $164.945 * *$ & $2.1441 * *$ & $0.9972 * *$ & $0.0681 * *$ & $0.0219 * *$ \\
\hline Linear & 1 & $3.208^{* * *}$ & $457.095 * *$ & $\mathbf{5 . 5 5 3 7} * *$ & $2.9505 * *$ & $\mathbf{0 . 1 0 2 0} * *$ & $0.0366 * *$ \\
\hline Quadratic & 1 & $0.166 * *$ & 26.684* & $0.8396 * *$ & 0.0136 & $\mathbf{0 . 1 0 0 3} * *$ & $0.0290 * *$ \\
\hline LOF & 1 & 0.074 & 11.057 & 0.0392 & 0.0275 & 0.0021 & 0.0001 \\
\hline$P$ rate & 3 & $0.166^{* *}$ & 7.061 & $0.3229 * *$ & 0.0155 & 0.0069 & $0.0063 * *$ \\
\hline Linear & 1 & $0.349 * *$ & 6.505 & $0.9497 * *$ & 0.0410 & 0.0131 & $0.0178 * *$ \\
\hline Quadratic & 1 & $0.148 *$ & 13.828 & 0.0173 & 0.0049 & 0.0024 & 0.0007 \\
\hline LOF & $\mathbf{1}$ & 0.002 & 0.852 & 0.0019 & 0.0004 & 0.0054 & 0.0006 \\
\hline$N$ rate $\times P$ rate & 9 & 0.042 & 5.436 & 0.1352 & 0.0401 & 0.0024 & 0.0008 \\
\hline Error & 45 & 0.023 & 5.792 & $0.0621^{*}$ & 0.0226 & 0.0031 & 0.0015 \\
\hline \multirow[t]{2}{*}{ SED } & & 0.107 & 1.702 & 0.1762 & 0.1063 & 0.0394 & 0.0274 \\
\hline & & \multicolumn{4}{|c|}{ Treatment means } & & \\
\hline \multicolumn{8}{|l|}{$\mathrm{N}$ rate, $\mathrm{kg} \mathrm{ha}^{-1}$} \\
\hline $\mathbf{0}$ & & 0.28 & 7.38 & 1.99 & 0.84 & 0.40 & 0.27 \\
\hline 67 & & 0.59 & 11.19 & 1.94 & 1.05 & 0.29 & 0.22 \\
\hline 134 & & 0.68 & 12.31 & 2.12 & 1.16 & 0.25 & 0.20 \\
\hline 269 & & 0.93 & 15.13 & 2.73 & 1.44 & 0.27 & 0.21 \\
\hline \multicolumn{8}{|l|}{$P$ rate, $\mathrm{kg} \mathrm{ha}^{-1}$} \\
\hline 0 & & 0.47 & 10.66 & 2.37 & 1.15 & 0.29 & 0.21 \\
\hline 22 & & 0.64 & 11.67 & 2.24 & 1.14 & 0.27 & 0.22 \\
\hline 45 & & 0.69 & 12.26 & 2.11 & 1.12 & 0.32 & 0.23 \\
\hline 269 & & 0.67 & 11.42 & 2.05 & 1.08 & 0.32 & 0.25 \\
\hline
\end{tabular}

* Significant at the 0.05 probability level.

** Significant at the 0.01 probability level.

$\uparrow$ df, degrees of freedom; LOF, lack of fit; SED, standard error of the difference between two equally replicated means.

growth corresponds to a decrease in plant $\mathrm{P}$ concentration with the plants having the higher biomass exhibiting the lower concentration due to dilution.

Grain yield increased by $29 \%$ in 1997 and $92 \%$ in 1998 for the $67 \mathrm{~kg} \mathrm{~N} \mathrm{ha}^{-1}$ rate over the $0 \mathrm{~kg} \mathrm{~N}^{-1}$ rate (Table 4). There was no significant difference in grain yield between the 134 and $269 \mathrm{~kg} \mathrm{~N}^{-1}$ rates in 1997; in 1998 the $269 \mathrm{~kg} \mathrm{~N}^{-1}$ rate had a significantly higher yield. Small yield differences in 1997 could be attributed to high residual soil nitrate levels before initiating the experiment. Response to applied $\mathrm{P}$ was only observed between the 0 and $22 \mathrm{~kg} \mathrm{P}^{-1}$ rates, with the three

Table 4. Analysis of variance, $\mathbf{N}$ and $\mathbf{P}$ rates means, and single degree of freedom contrasts for grain yield, $\mathbf{N}$, and $\mathbf{P}$ concentration, 1997 and 1998. $\dagger$

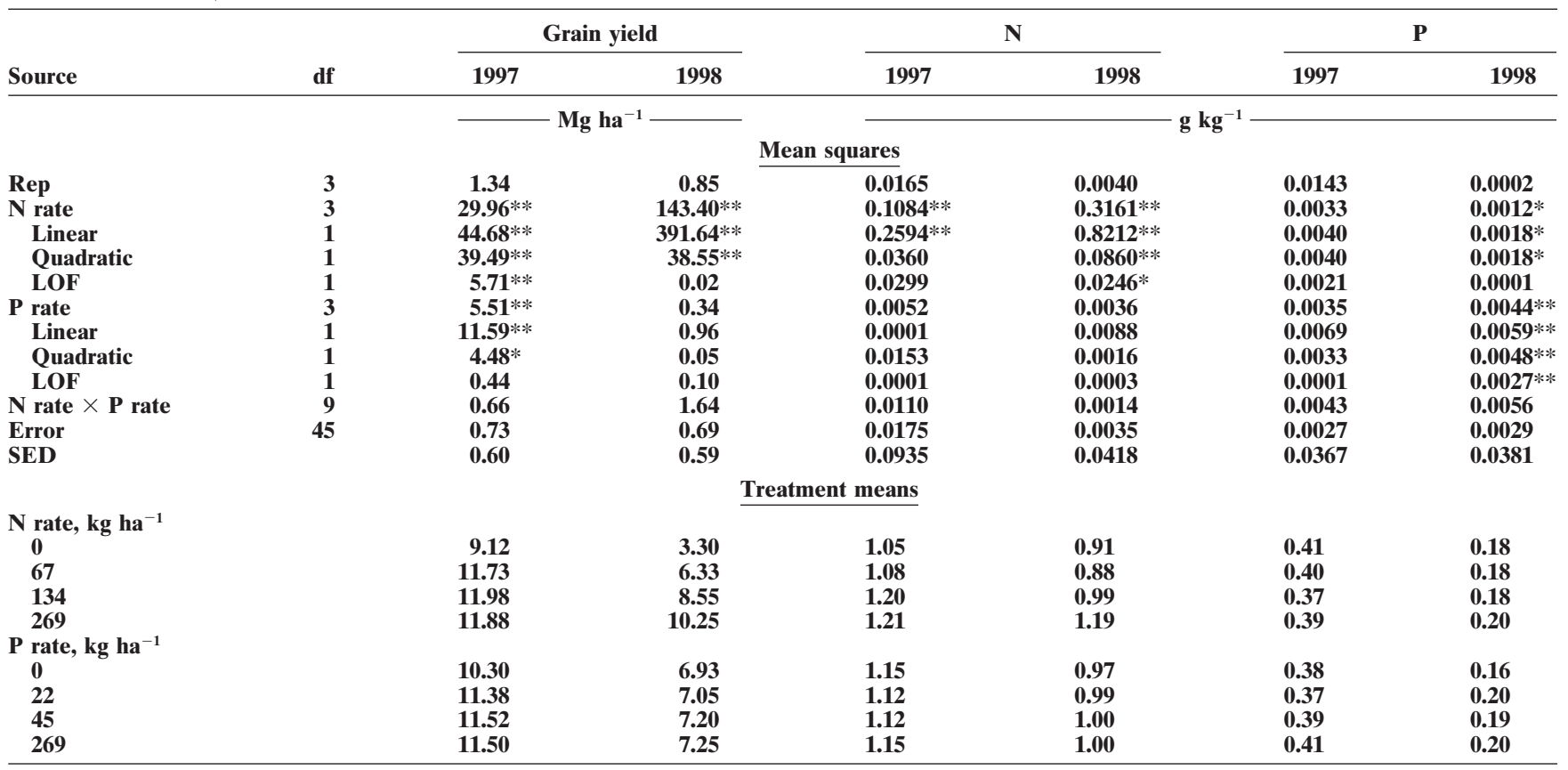

* Significant at the 0.05 probability level.

** Significant at the 0.01 probability level.

$\dagger$ df, degrees of freedom; LOF, lack of fit; SED, standard error of the difference between two equally replicated means. 
higher rates having a similar response in both years (Table 4).

\section{Hyperspectral Readings}

Integrating sphere measurements were collected only to distinguish between differenced $\mathrm{P}$ treatments; therefore, readings were limited to the $269 \mathrm{~kg} \mathrm{~N} \mathrm{ha}^{-1}$ treatment for the 1997 growing season. Regression analysis for the first two samplings (17 and 23 June) resulted in significant multiple regression equations for predicting P concentration, while the third sampling date (28 July) did not provide a significant equation for predicting total $\mathrm{P}$ (Table 5). At this time early season visual $\mathrm{P}$ deficiency symptoms were no longer present. Reflectance wavelengths used for predicting $\mathrm{P}$ concentration were in the NIR (730 and $930 \mathrm{~nm}$ ) region of the spectrum for the 17 June sampling with an $R^{2}=0.68$ (Table 5). According to Lillesand and Kiefer (1987), reflectance in the NIR region of the spectrum is due primarily to the internal structure of the plant leaves. Jacob and Lawlor (1991) found that the initial effect of P stress on corn, wheat, and sunflower was an increase in the number of smaller cells per unit of leaf area compared with a nonstressed plant. Such an increase in the number of cells would suggest that NIR reflectance might be important for predicting $\mathrm{P}$ content of plants. Analysis of data from the second sampling date identified blue reflectance as an important segment for predicting $\mathrm{P}$ content in the leaves. Reflectance at 440 and $445 \mathrm{~nm}$ was significant in predicting $\mathrm{P}$ with an $R^{2}=0.61$ (Table 5). Under $P$ stress, increases anthocyanin production causing a purple discoloration in the leave margins (Marchner, 1995). At V6 growth stage, purpling at the leave margins in the P stressed plots was observed. Salisbury and Ross (1978) stated that anthocyanin strongly absorbs in the green region while reflecting in the blue or red region of the spectrum, coinciding with the greater reflectance at 440 and $445 \mathrm{~nm}$. Biolley and Jay (1993) characterized the colorimetric features of modern roses in relation to anthocyanin content, finding that petals containing large amounts of anthocyanin exhibited an increased reflectance between 400 to $580 \mathrm{~nm}$ compared with petals containing less anthocyanin. Further analysis of reflectance at these two wavelengths showed that reflectance was significantly higher at $440 \mathrm{~nm}$ for the $67 \mathrm{~kg}$ $\mathrm{P} \mathrm{ha}^{-1}$ compared with the 22 and $45 \mathrm{~kg} \mathrm{P}^{-1}$ rates at the 0.05 probability level (Fig. 2). Reflectance at $445 \mathrm{~nm}$ decreased with increasing $\mathrm{P}$ rates, which explains the difference in the sign of the coefficient for the 440 and $445 \mathrm{~nm}$ segments (Fig. 2 and Table 5). Reflectance for the $0 \mathrm{~kg} \mathrm{P} \mathrm{ha}{ }^{-1}$ rate had a higher reflectance from 435 to $460 \mathrm{~nm}$.

Table 5. Regression equations by sampling date for predicting $\mathbf{P}$ concentration from integrating sphere hyperspectral data at the $269 \mathrm{~kg} \mathrm{~N}^{-1} \mathrm{~N}$ rate.

\begin{tabular}{llcl}
\hline Date & $\begin{array}{c}\text { Growth } \\
\text { stage }\end{array}$ & $\boldsymbol{R}^{2}$ & \multicolumn{1}{c}{ P concentration, $\mathrm{g} \mathrm{kg}^{-1} \dagger$} \\
\hline 17 June 1997 & V6 & $\mathbf{0 . 6 8}$ & $\boldsymbol{y}=\mathbf{0 . 0 8 5}-\mathbf{0 . 0 3 1} \times \boldsymbol{R}_{730}+\mathbf{0 . 0 2 7} \times \boldsymbol{R}_{930}$ \\
23 June 1997 & V7-V8 & $\mathbf{0 . 6 1}$ & $\boldsymbol{y}=\mathbf{0 . 3 0 4}+\mathbf{0 . 1 4 8} \times \boldsymbol{R}_{440}-\mathbf{0 . 1 6 0} \times \boldsymbol{R}_{445}$ \\
29 July 1997 & V9-V11 & & No significant equation \\
\hline
\end{tabular}

$\dagger R_{x}$ : reflectance data collected at the specified wavelengths, $\pm 2.5 \mathrm{~nm}$.

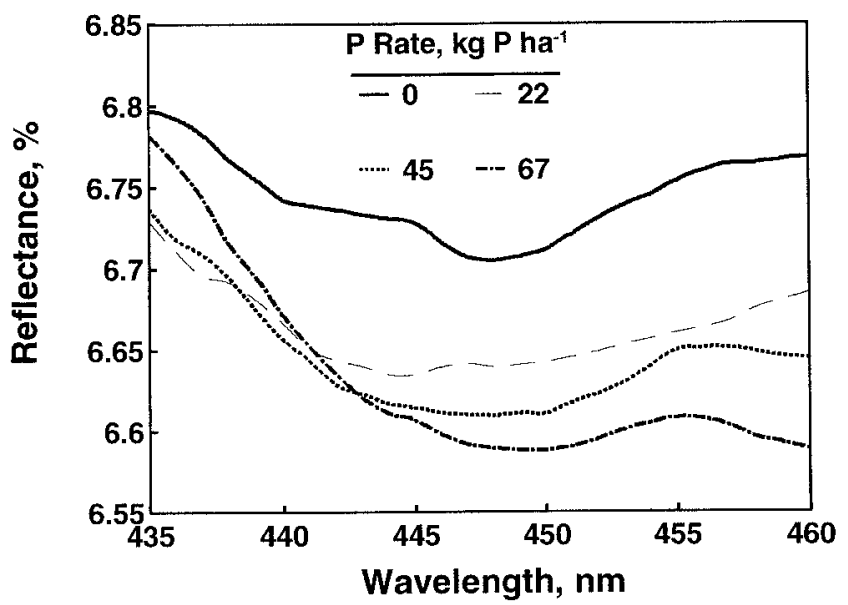

Fig. 2. Segment of spectral curve for integrating sphere measurement at the $269 \mathrm{~kg} \mathrm{~N} \mathrm{ha}^{-1}$ rate, 23 June 1997.

Canopy measurements taken during 1997 and 1998 included both plant and soil reflectance. Therefore, during the growing season as the canopy closed, there was progressively less soil visible to interact with the canopy reflectance. Unlike the integrating sphere measurements, analysis of canopy measurements included all treatments. Therefore, prediction of $\mathrm{N}$ concentration was with and without the presence of $\mathrm{P}$ stress, and prediction of $\mathrm{P}$ concentration was with and without the presence of $\mathrm{N}$ stress. Stepwise regression for estimating plant $\mathrm{N}$ and $\mathrm{P}$ and total biomass was performed on those dates corresponding to a plant sampling dates. During the 1997 growing season, there were no significant multiple regression equations developed for predicting $\mathrm{P}$ or $\mathrm{N}$ content for the June sampling (Table 6). The equation for predicting total biomass was statistically significant $\left(R^{2}=0.43\right)$, but was not considered to be a very good indicator of total biomass. Data from the 15 July sampling provided a better prediction of total biomass with an $R^{2}=0.68$ (Table 6 ). One of the factors that could have contributed to the inability to predict $\mathrm{P}$ and $\mathrm{N}$ content or biomass for the June 1997 sampling date was the method by which the readings were collected. The field of view for the fore-optic was not strictly centered over the row at all times; therefore, the readings could have contained a greater proportion of soil background compared with vegetation. After the 19 June 1997 sampling, the fore-optic was centered over the row to minimize the amount of soil present. The July 1997 sampling resulted in an equation for predicting $\mathrm{N}$ concentration in the plant using reflectance in the red and NIR region of the spectrum with an $R^{2}=0.81$ (Table 6). Different researchers have used reflectance or developed indices using reflectance at these wavelengths to identify $\mathrm{N}$ stress (Walburg et al., 1982; Blackmer et al., 1996; and Stone et al., 1996).

Overall, the 1998 growing season resulted in a greater ability to predict $\mathrm{N}$ and $\mathrm{P}$ content and biomass due to the larger response to applied fertilizers. Prediction of plant $\mathrm{P}$ was best for the June sampling date using reflectance in the blue and NIR regions with an $R^{2}=0.61$ (Table 6). Reflectance in these regions is attributed to internal cell structure and the presence of anthocyanin in the P stressed plots compared with the nonstressed 
Table 6. Regression equations for predicting biomass, $\mathbf{N}$, and $\mathbf{P}$ concentration from canopy hyperspectral data by sampling date.

\begin{tabular}{|c|c|c|c|}
\hline Date & Growth stage & $\boldsymbol{R}^{2}$ & Biomass, $\mathrm{kg} \mathrm{ha}^{-1} \dagger$ \\
\hline 19 June 1997 & V6 & 0.43 & $y=705-1030 \times R_{535}+860 \times R_{565}+37 \times R_{805}$ \\
\hline 15 July 1997 & V14-VT & 0.63 & $y=5528+2461 \times R_{740}-2316 \times R_{760}+1341 \times R_{850}+4447 \times R_{905}-4987 \times R_{920}+93 \times R_{980}$ \\
\hline 19 June 1998 & V5-V7 & 0.87 & $\begin{aligned} y= & \underset{709}{701122} \times R_{405}-2536 \times R_{415}+1612 \times R_{440}-1877 \times R_{465}+1836 \times R_{5} \% 1 \% 0+364 \\
& \times R_{615}+17 \times R_{975}\end{aligned}$ \\
\hline \multirow[t]{2}{*}{20 July 1998} & V14-R1 & 0.68 & $\begin{aligned} y= & -1038+14239 \times R_{435}+35473 \times R_{450}+15347 \times R_{475}+25107 \times R_{700}+20295 \times R_{710} \\
& +4167 \times R_{950}-\mathbf{3 7 3 9} \times R_{960}\end{aligned}$ \\
\hline & & & $\underline{\mathrm{N} \text { concentration, } \mathbf{g ~ k g}^{-1}}$ \\
\hline 19 June 1997 & V6 & & No significant equation \\
\hline 15 July 1997 & V14-VT & 0.81 & $\begin{aligned} y= & \mathbf{0 . 7 6 4}-4.844 \times R_{600}+2.577 \times R_{610}+1.698 \times R_{625}+0.734 \times R_{700}+0.427 \times R_{805}-0.373 \\
& \times R_{875}+0.039 \times R_{975}-0.029 \times R_{980}\end{aligned}$ \\
\hline 19 June 1998 & V5-V7 & 0.78 & $\begin{aligned} y= & 1.232+1.944 \times R_{420}-1.347 \times R_{565}+1.431 \times R_{615}-5.802 \times R_{650}+2.647 \times R_{655}+1.529 \\
& \times R_{725}+0.102 \times R_{945}-0.035 \times R_{990}\end{aligned}$ \\
\hline \multirow[t]{2}{*}{20 July 1998} & V14-R1 & 0.64 & $y=0.822+0.232 \times R_{740}-0.244 \times R_{745}+0.0401 \times R_{975}$ \\
\hline & & & $\underline{P}$ concentration, $\mathbf{g ~ k g}^{-1}$ \\
\hline 19 June 1997 & V6 & & No significant equation \\
\hline 15 July 1997 & V14-VT & & No significant equation \\
\hline 19 June 1998 & V5-V7 & 0.61 & $y=-0.023-0.219 \times R_{405}+0.305 \times R_{415}+0.428 \times R_{900}-0.184 \times R_{905}-0.241 \times R_{920}$ \\
\hline 20 July 1998 & V14-R1 & 0.36 & $y=0.285+0.022 \times R_{570}-0.06 \times R_{770}$ \\
\hline
\end{tabular}

$\dagger R_{\mathrm{x}}$ : reflectance data collected at the specified wavelengths, $\pm 2.5 \mathrm{~nm}$.

plots. As previously mentioned, the ability to predict $\mathrm{P}$ later in the season was not very effective. Difference in positive and negative regression equations coefficient for wavelengths can be explained by slope shifts in the reflectance spectra at each particular wavelength for the different $\mathrm{P}$ levels. The ability to predict biomass was better in 1998 than 1997 while predicting $\mathrm{N}$ content was best for the 15 July 1997 sampling. The July sampling date in 1997 was the only date with a significant equation; both sampling dates in 1998 had significant equations for predicting $\mathrm{N}$ content. Prediction of $\mathrm{N}$ concentration was accomplished using reflectance in a number of different regions of the spectrum including chlorophyll absorption, green, red, and NIR for the June sampling $\left(R^{2}=0.78\right)$ (Table 6). The equation for the July sampling used primarily reflectance in the NIR region, which could be attributed to differences in biomass at this growth stage. At this particular sampling date, the low $\mathrm{N}$ treatments were at a late vegetative growth stage (V13) while the high $\mathrm{N}$ treatments were in a reproductive stage (R1). Plants from the low $\mathrm{N}$ treatment were also visibly less vigorous compared with those from the high $\mathrm{N}$ treatments. Prediction of total biomass was best for the June sampling with an $R^{2}=0.87$ whereas the July sampling had an $R^{2}=0.68$. Reflectances for these equations were composed of the different reflectance wavelengths for predicting plant $\mathrm{N}$ and $\mathrm{P}$ content (Table 6).

Stepwise regression was performed to estimate grain yield, and grain $\mathrm{N}$ and $\mathrm{P}$ content using the hyperspectral data for all sampling dates (Table 7). Prediction of grain yield was best using the 1998 data with $R^{2}>0.84$ and the best date in 1998 was 20 July. Data collected on 19 June 1997 exhibited difficulties in predicting any of the

Table 7. Regression equations for predicting grain yield, and grain $\mathbf{N}$, and $\mathbf{P}$ from canopy hyperspectral data by measurement collection date.

\begin{tabular}{|c|c|c|c|}
\hline Date & Growth stage & $R^{2}$ & Grain yield, $\mathrm{Mg} \mathrm{ha}^{-1} \dot{\dagger}$ \\
\hline 19 June 1997 & V6 & $\mathbf{0 . 3 4}$ & $y=\mathbf{1 4 . 8 3 6}+7.985 R_{525} \dagger-7.416 \times R_{565}$ \\
\hline 15 July 1997 & V14-VT & 0.78 & $\begin{aligned} y= & 6.823+1.770 \times R_{730}-1.794 \times R_{760}+7.812 \times R_{875}-9.229 \times R_{880}+5.061 \times R_{890}-3.724 \times R_{920} \\
& +1.232 \times R_{965}-0.211 \times R_{995}\end{aligned}$ \\
\hline 19 June 1998 & V5-V7 & 0.88 & $y=9.765-7.326 \times R_{580}+7.770 \times R_{625}-8.180 \times R_{725}+6.418 \times R_{730}+\mathbf{0 . 1 8 4} \times R_{980}$ \\
\hline 24 June 1998 & V6-V8 & 0.84 & $\boldsymbol{y}=\mathbf{5 . 9 3 3}-\mathbf{8 . 7 5 0} \times \boldsymbol{R}_{555}+\mathbf{4 . 4 8 7} \times \boldsymbol{R}_{740}$ \\
\hline 29 June 1998 & V8-V11 & 0.89 & $y=4.823-13.804 \times R_{670}+11.790 \times R_{710}-0.893 \times R_{995}+1.721 \times R_{960}-0.480 \times R_{965}-0.114 \times R_{995}$ \\
\hline \multirow[t]{2}{*}{20 July 1998} & V14-R1 & 0.90 & $y=4.410+0.713 \times R_{760}+1.408 \times R_{920}+1.107 \times R_{935}-1.972 \times R_{945}$ \\
\hline & & & $\underline{N}$ concentration, $\mathbf{g ~ k g}^{-1}$ \\
\hline 19 June 1997 & V6 & & No significant equation \\
\hline 15 July 1997 & V14-VT & 0.37 & $y=0.974-0.425 \times R_{565}+0.521 \times R_{600}+0.016 \times R_{950}$ \\
\hline 19 June 1998 & V5-V7 & 0.84 & $\begin{aligned} \boldsymbol{y}= & \mathbf{0 . 6 9 9}+\mathbf{0 . 2 8 6} \times \boldsymbol{R}_{420}+\mathbf{0 . 5 7 3} \times \boldsymbol{R}_{465}-\mathbf{1 . 7 0 1} \times \boldsymbol{R}_{505}+\mathbf{1 . 2 1 6} \times \boldsymbol{R}_{510}-\mathbf{1 . 4 3 8} \times \boldsymbol{R}_{580}+\mathbf{1 . 1 3 8} \times \boldsymbol{R}_{585} \\
& -\mathbf{0 . 6 9 9} \times \boldsymbol{R} 7_{10}+\mathbf{0 . 6 8 0} \times \boldsymbol{R}_{715}+\mathbf{0 . 0 4 8} \times \boldsymbol{R}_{050}-\mathbf{0 . 0 0 8} \times \boldsymbol{R}_{080}\end{aligned}$ \\
\hline 24 June 1998 & V6-V8 & 0.85 & $\begin{aligned} y= & 0.758+0.524 \times R_{420}+1.147 \times R_{525}-1.010 \times R_{555}-0.862 \times R_{635}+0.601 \times R_{640}-0.674 \times R_{700} \\
& +0.927 \times R_{730}-\mathbf{0 . 3 5 2} \times R_{745}+\mathbf{0 . 1 6 8} \times R_{935}-\mathbf{0 . 8 4 4} \times R_{965}\end{aligned}$ \\
\hline 29 June 1998 & V8-V11 & 0.78 & $\begin{aligned} \boldsymbol{y}= & \mathbf{1 . 0 3 4}+\mathbf{0 . 2 8 7} \times \boldsymbol{R}_{520}-\mathbf{0 . 5 1 3} \times \boldsymbol{R}_{555}+\mathbf{0 . 4 6 2} \times \boldsymbol{R}_{745}-\mathbf{0 . 4 7 7} \times \boldsymbol{R}_{760}+\mathbf{0 . 3 1 1} \times \boldsymbol{R}_{785}+\mathbf{0 . 0 7 5} \times \boldsymbol{R}_{915} \\
& -\mathbf{0 . 1 5 9} \times \boldsymbol{R}_{935}-\mathbf{0 . 0 1 0} \times \boldsymbol{R}_{980}\end{aligned}$ \\
\hline 20 July 1998 & V14-R1 & 0.82 & $\begin{array}{c}y=0.884+0.760 \times R_{430}-0.973 \times R_{435}+0.277 \times R_{535}-0.099 \times R_{760}+0.054 \times R_{965} \\
P \text { concentration, } \mathbf{g ~ k g}^{-1}\end{array}$ \\
\hline 19 June 1997 & V6 & & No significant equation \\
\hline 15 July 1997 & V14-VT & & No significant equation \\
\hline 19 June 1998 & V5-V7 & 0.20 & $y=0.203-0.005 \times R_{745}+0.003 \times R_{975}$ \\
\hline 24 June 1998 & V6-V8 & 0.41 & $y=0.240-0.408 \times R_{460}+0.287 \times R_{495}+0.573 \times R_{540}-0.399 \times R_{550}-0.067 \times R_{730}+0.002 \times R_{990}$ \\
\hline 29 June 1998 & V8-V11 & & No significant equation \\
\hline 20 July 1998 & V14-R1 & & No significant equation \\
\hline
\end{tabular}

$\dagger R_{x}$ : reflectance data collected at the specified wavelengths, $\pm 2.5 \mathrm{~nm}$. 
three variables due probably to the collection method mentioned previously. Only the first two sampling dates in 1998 resulted in a statistically significant equation for predicting grain $\mathrm{P}$. The ability to predict grain $\mathrm{N}$ was better for 1998 than 1997 in part due to the greater response to applied $\mathrm{N}$ in 1998. The wavelengths of reflectance important for predicting $\mathrm{N}$ occurred throughout the spectrum and changed throughout the growing season. These differences could be due to differences in the amount of soil background present, difference in growth stages, or a number of other factors. The wavelengths used to predict total biomass and grain yield were a combination of the wavelengths important for predicting $\mathrm{N}$ and $\mathrm{P}$ content of the plant.

\section{CONCLUSIONS}

The study demonstrated hyperspectral data can be used for estimating $\mathrm{N}$ and $\mathrm{P}$ concentration, biomass, and grain yield under the presence of a combination of nutrient stresses. Prediction of plant $\mathrm{P}$ was best in the early growth stages (before V8) using reflectance in the blue (440 and $445 \mathrm{~nm}$ ) and NIR (730 and $930 \mathrm{~nm}$ ) regions, while $\mathrm{N}$ concentration could be predicted throughout the growing season. Important reflectance wavelengths for predicting $\mathrm{N}$ content, biomass, and grain yield changed with sampling date, possibly due to the differences in percentage ground cover and growth stage. There was a greater response to applied $\mathrm{N}$ in the second year of the study with greater differences in yield and nutrient concentration between $\mathrm{N}$ rates. Effect of applied $\mathrm{P}$ was only between the $0 \mathrm{~kg} \mathrm{P} \mathrm{ha}^{-1}$ and the $22 \mathrm{~kg} \mathrm{P} \mathrm{ha}^{-1}$, with no differences between the three highest $\mathrm{P}$ rates. Estimation of grain yield was best accomplished by using spectral data from the late July sampling date. Reflectance wavelengths used to estimate grain yield were a combination of those used to estimate $\mathrm{N}$ and $\mathrm{P}$ content for each particular growth stage. Reflectance in the near-infrared (NIR) and blue regions was found to predict early season $\mathrm{P}$ stress between growth stages V6 and V8. Late-season detection of P stress was not achieved. Plant $\mathrm{N}$ concentration was best predicted using reflectance in the red and green regions of the spectrum, while grain yield was estimated using reflectance in the NIR region, with the particular wavelengths of importance changing with growth stage.

\section{REFERENCES}

Al-Abbas, A.H., R. Barr, J.D. Hall, F.L. Crane, and M.F. Baumgardner. 1974. Spectra of normal and nutrient-deficient maize leaves. Agron. J. 66:16-20.

Blackmer, T.M., and J.S. Schepers. 1994. Techniques for monitoring crop nitrogen status in corn. Commun. Soil Sci. Plant Anal. 25: 1791-1800.

Blackmer, T.M., J.S. Schepers, and G.E. Varvel. 1994. Light reflectance compared with other nitrogen stress measurement in corn leaves. Agron. J. 86:934-938.

Blackmer, T.M., J.S. Schepers, G.E. Varvel, and E.A. Walter-Shea. 1996. Nitrogen deficiency detection using reflected shortwave radiation from irrigated corn canopies. Agron. J. 88:1-5.

Biolley, J.P., and M. Jay. 1993. Anthocyanins in modern roses: Chemical and colorimetric features in relation to the colour range. J. Exp. Bot. 44:1725-1734.

Everitt, J.H., A.J. Richardson, and H.W. Gausman. 1985. Leaf reflectance-nitrogen-chlorophyll relations in buffelgrass. Photogramm. Eng. Remote Sens. 51:463-466.

Jacob, J., and D.W. Lawlor. 1991. Stomatal and mesophyll limitations of photosynthesis in phosphate deficient sunflower, maize and wheat plants. J. Exp. Bot. 42:1003-1011.

Knudsen, D., R.B. Clark, J.L. Denning, and P.A. Pier. 1981. Plant analysis of trace elements by x-ray. J. Plant Nutr. 3:61-75.

Lillesand, T.M., and R.W. Kiefer. 1987. Remote sensing and image interpretation. 2nd ed. John Wiley \& Sons, New York.

Marchner, H. 1995. Mineral nutrition of higher plants. 2nd ed. Academic Press, New York.

Masoni, A., L. Ercoli, and M. Mariotti. 1996. Spectral properties of leaves deficient in iron, sulfur, magnesium, and manganese. Agron. J. 88:937-943.

Milton, N.M., B.A. Eiswerth, and C.M. Ager. 1991. Effect of phosphorus deficiency on spectral reflectance and morphology of soybean plants. Remote Sens. Environ. 36:121-127.

Ritchie, S.W., J.J. Hanway, and G.O. Benson. 1997. How a corn plants develops. Spec. Pub. 48. Iowa State Univ. of Sci. and Tech. Coop. Ext. Service, Ames, IA.

Salisbury, F.B., and C.W. Ross. 1978. Plant physiology. 2nd ed. Wadsworth Publ. Co., Belmont, CA.

SAS Institute. 1988. SAS/STAT procedures. Release 6.03 ed. SAS Inst., Cary, NC.

Schepers, J.S., D.D. Francis, and M.T. Tompson. 1989. Simultaneous determination of total $\mathrm{C}$, total $\mathrm{N}$ and ${ }^{15} \mathrm{~N}$ on soil and plant material. Commun. Soil Sci. Plant Anal. 20:949-959.

Sembiring, H., W.R. Raun, G.V. Johnson, M.L. Stone, J.B. Solie, and S.B. Phillips. 1998. Detection of nitrogen and phosphorus nutrient status in bermudagrass using spectral radiance. J. Plant Nutr. 21: 1189-1206.

Stone, M.L., J.B. Solie, W.R. Raun, R.W. Whitney, S.L. Taylor, and J.D. Ringer. 1996. Use of spectral radiance for correcting in-season fertilizer nitrogen deficiencies in winter wheat. Trans. ASAE 39: 1623-1631.

Walburg, G., M.E. Bauer, C.S.T. Daughtry, and T.L. Housley. 1982. Effects of nitrogen nutrition on the growth, yield, and reflectance characteristics of corn canopies. Agron. J. 74:677-683.

Yoder, B.J., and R.E. Pettigrew-Crosby. 1995. Predicting nitrogen and chlorophyll content and concentrations from reflectance spectra (400-2500 nm) at leaf and canopy scales. Remote Sens. Environ. 53:199-211. 